\title{
ВОЗМОЖНОСТИ РУБЛЯ \\ В ГЕОПОЛИТИЧЕСКИХ УСЛОВИЯХ ЕДИНОГО ЭКОНОМИЧЕСКОГО ПРОСТРАНСТВА
}

\begin{abstract}
Аннотация. В статье рассмотрены возможности Единого экономического пространства (ЕЭП), формируемого Россией, Казахстаном и Белоруссией как инструмент противодействия «внешним силам» с иелью защиты интересов его участников в системе международной конкурениии государств и их альянцев, показываются возможности, перспективы и трудности функиионирования ЕЭП как среды для формирования единой региональной резервной валюты. Обсуждаются некоторые аспекты перспектив российского рубля как региональной резервной валюты ЕЭП. Автором сделан вывод: для того чтобы валюта конкретного государства приобрела статус региональной резервной валюты, должно быть обеспечено такое развитие экономики страны её эмитента, при котором она, во-первых, станет основным конечным потребителем товаров и услуг, производимых в соседних странах, во-вторых, будет инвестировать средства в активы стран-партнеров, в-третьих, будет в состоянии обеспечивать приемлемую доходность по активам, номинированным в своей валюте. Дальнейшее укрепление авторитета рубля и расширение выраженных в нем операций мирового рынка в немалой степени связано с тем, насколько Россия в дальнейтем будет проявлять активность в борьбе за демократизацию мировой финансовой архитектуры. Кроме всего прочего это будет способствовать и укреплению роли рубля на территории постсоветских государств и их союзов.
\end{abstract}

Ключевые слова: Единое экономическое пространство, мировая резервная валюта, начиональная резервная валюта, условия, факторы, перспективы формирования, укрепление роли рубля, мировой рынок, государство, эмитент.

Abstract: This article reviews the possibilities of the Common Economic Space (CES) that is being formed by Russia, Kazakhstan, and Belarus as an instrument of counteracting the "external forces" for the purpose of protecting the interests of its members within the system of international competition of nations and their alliances. It reveals the possibilities, opportunities and difficulties associated with the functioning of the CES as an environment for the forming of a unified regional reserve currency with the Russian ruble as such currency. The author comes to a conclusion that in order for a currency of a particular country to gain the status of the regional reserve currency, it is necessary for this country (the issuer) to demonstrate such level of economic growth that it would be able to become the main consumer of the products and services manufactured in the neighboring countries; invest into the assets of the partnering nations; ensure an acceptable profitability of the assets denominated in their currency. The further strengthening of the ruble and growth in the number of operations involving ruble on the global market is closely tied to how active Russia will be in the fight for democratization of the global financial structure. This will also contribute to the strengthening of the ruble within the post-Soviet territory and their alliances.

Keywords: Common Economic Space, global reserve currency, national reserve currency, ruble, global market, issuer, global economy.

\section{Краткая предыстория вопроса}

октябре 2010 года был рассмотрен вопрос о создании, в рамках ЕврАзЭС, Единого экономического пространства России, Белоруссии и Казахстана (ЕЭП). В декабре 2010 года президенты этих стран подписали пакет документов, заложивших нормативные основы ЕЭП. В качестве цели формирования ЕЭП ${ }^{1}$ - как

\footnotetext{
${ }^{1}$ Источник: материалы Интернет-ресурса www.group-global.org интеллектуальная сеть Ассоциации «Евразийский
} 
масштабного экономико-геополитического проекта - обозначено «создание условий для стабильного и эффективного развития экономик государств-участников и повышения уровня жизни населения». ${ }^{2}$

Базовые правила макроэкономического регулирования взаимодействия и взаимоотношений в рамках ЕЭП, сходны с теми, что были в свое время установлены Маастрихтским договором для стран-участниц Евросоюза. Это - дефицит бюджета каждой из стран не должен превышать $3 \%$ её ВВП, государственный долг - 50\% её ВВП, инфляция не должна превышать самый низкий показатель среди всех стран объединения более чем на 5 процентных пунктов.

Принцип «четырех свобод», также исповедуемый участниками европейской экономической интеграции, заложен и в основу формирования ЕЭП. Это - обеспечение свободы движения товаров, услуг, капитала и рабочей силы через границы государств-участников. Примечательно, что опыт ЕС, в данном случае, был принят за образец для ЕЭП по причине отсутствия более удачных примеров (по образному замечанию, высказанному в свое время премьер-министром Республики Казахстан Каримом Масимовым).

Принцип свободного перемещения товаров предусматривает снятие ограничений во взаимной торговле на основе унификации таможенных тарифов, формирования общего таможенного тарифа, мер нетарифного регулирования, применения инструментов регулирования торговли товарами с третьими странами, а также-устранение изъятий из режима свободной торговли. Свободное движение товаров, услуг, капитала, рабочей силы создает предпосылки для эффективного развития за счет снижения ценовых и бюрократических барьеров, ускорения экономических процессов, снижения вре-

экономический клуб ученых» в формате коммуникативной интернет-площадки G-Global.

${ }^{2}$ Источник: www.kremlin.ru/terms/e менных издержек, создания новых рынков сбыта. В этом - несомненные преимущества интеграционных процессов, реализующихся в рамках ЕЭП. ${ }^{3}$

Согласно принятой руководителями Белоруссии, Казахстана и России декларации, за начало функционирования ЕЭП принята дата 1 января 2012 года; несколько последующих лет отводится на работу по унификации национальных законодательств, связанных с экономическим регулированием. И эта декларация не осталась лишь в ряду благих намерений.

Так, с 1 января 2013 года в ЕЭП был унифицирован железнодорожный тариф, ведется работа по введению единого режима по госзакупкам. Начиная с 2012 года, идея Единого экономического пространства (ЕЭП) реализуется на уровне Таможенного Союза России, Беларуси и Казахстана, который охватывает 165 млн. жителей этих стран.

Ожидается, что к 2015 году Единое экономическое пространство будет трансформировано в Евразийский экономический союз, который станет полноценным, открытым для вступления других стран экономическим блоком, - подобно Евросоюзу, - с общей валютой, унифицированными национальными законодательствами и хорошо скоординированными экономической и денежной политикой.

В наши дни Евразийская интеграция приобретает особую важность для большинства стран региона. Ведь, конкуренции государств в глобальной экономике сегодня выходит на уровень соперничества между интеграционными блоками. Это относится и к Европейскому и к Евразийскому союзам.

Объединение экономических, политических, людских и управленческих ресурсов в рамках ЕЭП способно принести странам-участницам множество выгод, способных про-

\footnotetext{
${ }^{3}$ По материалам интернет-портала Kapital.kz. Источник: kapital.kz/expert/12599/eep-otkroet-vozmozhnosti-ne-dlya-vseh.htm
} 
явиться в экономике, а также в социальной и политической сферах.

Наиболее важные аспекты привлекательности в области экономики.

Ускорение развития экономики в регионе, создание новых рабочих мест и увеличение доходов, а также реальное обеспечение для предпринимателей свободы выбора страны или административной территории регистрации своего бизнеса - что может быть обеспечено совокупностью следующих взаимопереплетающихся обстоятельств.

Это: обеспечение предпринимательскому корпусу условий для производства конкурентоспособной продукции и модернизации предприятий; Общий, интегрированный рынок, в случае его полноценного создания, окажется более привлекательным для взаимного инвестирования и инвестиций «третьих стран»; расширение возможностей доступа к инфраструктуре в области энергетики, коммуникаций и транспорта; повышение продуктивности взаимодействия бизнеса и власти.

Существенное облегчение свободы перемещения в пределах трех стран капиталов, трудовых ресурсов и услуг, обусловленное созданием в 2011 г. Таможенного Союза этих стран, по существу, открыло реальные перспективы к институциональному формированию реально функционирующего общего экономического пространства.

Ключевые аспекты привлекательности в социальном плане.

Оптимизация отношений на рынке труда, как следствие упрощения условий перемещения рабочей силы и повышение покупательной способности населения, могли бы привести к снижению социальной напряженности в странах-участницах и, способствовать преодолению деформаций на рынках жилья, сложившихся еще в советское время и непреодоленных и по сей день.

В этой связи, уместно привести мнение C. Глазьева, высказанное, правда, по пово- ду Таможенного Союза, согласно которому, преимущество состоит в таком объединении экономик входящих в него стран, которое способно обеспечить сочетание их национальных преимуществ и особенностей, что порождает новое качество. Как он полагает, единое экономическое пространство в наибольшей степени способно принести выгоды именно Беларуси, экономика которой явно ориентирована на внешнюю торговлю. Это определяется тем, что любой барьер, «автоматически» создает проблемы в сфере её конкурентоспособности. И ее стремление к объединению, даже несколько большее, чем демонстрируют другие страны-участницы процесса, обусловлено тем, что она больше других теряет вследствие дезинтеграции. При этом, С. Глазьев особо подчеркивает то, что создание единого экономического пространства, не говоря уже о Таможенном Союзе, должно сопрягаться с поиском реального баланса интересов, отражающего реальные вклад, мощность и значимость соответствующих национальных экономик. ${ }^{4}$

Наиболее упорядоченное изложение понимания того, какие выгоды приносит взаимодействие стран в рамках Таможенного союза и Единого экономического пространства, и в каких формах оно способствует укреплению национальных экономик, упрочению экономических связей и выходу стран-участниц на новый уровень интеграционного взаимодействия представлено в работе Е.В. Костюченко (см. таблицу).

\footnotetext{
${ }^{4}$ Глазьев С. Общий бонус и частные перспективы / С. Глазьев // Экономическая газета. - 2010, 9 августа.

${ }_{5}^{5}$ Костюченко E.B. Экономическая интеграция стран Таможенного Союза России, Белоруссии, Казахстана в мировое сообщество / Известия ВолгГТУ. Серия Актуальные проблемы реформирования российской экономики (теория, практика, перспектива): Межвузовский сб. науч. статей. Выпуск 14, № 16(103). Волгоград, 2012. C. 29-34.
} 


\section{Таблица - Взаимодействие стран-участниц Таможенного союза}

\begin{tabular}{|c|c|c|}
\hline Формат взаимодействия & Результат взаимодействия & Экономический эффект \\
\hline $\begin{array}{l}\text { Россия - Белоруссия - Ка- } \\
\text { захстан }\end{array}$ & $\begin{array}{l}\text { Таможенный союз; единое эконо- } \\
\text { мическое пространство; наднаци- } \\
\text { ональный орган регулирования - } \\
\text { комиссии Таможенного союза }\end{array}$ & $\begin{array}{l}\text { Свободное движение товаров на основе } \\
\text { унификации таможенных тарифов; фор- } \\
\text { мирование общего таможенного тарифа, } \\
\text { мер нетарифного регулирования; приме- } \\
\text { нение инструментов регулирования тор- } \\
\text { говли товарами с третьими странами. }\end{array}$ \\
\hline Россия - Белоруссия & $\begin{array}{l}\text { Договор о создании Союзного го- } \\
\text { сударства }\end{array}$ & $\begin{array}{l}\text { Для России: } \\
\text { Белоруссия - транзитный коридор с Евро- } \\
\text { пой. Возможность влияния в целях укре- } \\
\text { пления позиций в мировой экономике. } \\
\text { Для Белоруссии: } \\
\text { доступ к российским рынкам и дешевым } \\
\text { энергоресурсам. } \\
\text { Россия - крупнейший экспортер товаров. }\end{array}$ \\
\hline Россия - Казахстан & $\begin{array}{l}\text { Совместное участие в составе } \\
\text { основных экономических, воен- } \\
\text { но-политических международных } \\
\text { организациях }\end{array}$ & $\begin{array}{l}\text { Для России: } \\
\text { наличие большого количества товарных } \\
\text { и транспортных потоков. } \\
\text { наличие в Казахстане важных природ- } \\
\text { ных ресурсов. } \\
\text { Для Казахстана: } \\
\text { возможность развития внутреннего рын- } \\
\text { ка с перспективой выхода в мировую } \\
\text { экономику; защищенность от экономиче- } \\
\text { ского давления Китая. }\end{array}$ \\
\hline Белоруссия - Казахстан & $\begin{array}{l}\text { Договор о дружбе и сотрудниче- } \\
\text { стве. } \\
\text { Договор о долгосрочном экономи- } \\
\text { ческом сотрудничестве на 2009- } \\
2016 \text { гг. }\end{array}$ & $\begin{array}{l}\text { Укрепление торгово-экономического } \\
\text { сотрудничества вследствие увеличения } \\
\text { экспортно-импортных операций. }\end{array}$ \\
\hline
\end{tabular}

Общая же хроника вызревания интеграционных начинаний в рамках ЕЭП такова. ${ }^{6}$

6 октября 2007 года главами государств Республики Беларусь, Республики Казахстан и Российской Федерации подписан Договор о создании единой таможенной

${ }^{6}$ Хроника событий приведена по материалам Интернетpecypca www.group-global.org - интеллектуальная сеть Ассоциации «Евразийский экономический клуб ученых» в формате коммуникативной интернет-площадки G-Global. (Источник: www.group-global.org/aef?page=3) территории и формировании Таможенного союза (ТC) в целях обеспечения свободного перемещения товаров во взаимной торговле и благоприятных условий торговли ТС с третьими странами, а также развития экономической интеграции Сторон; базой для подписания явился Договор об учреждении Евразийского экономического сообщества от 10 октября 2000 года.

Июль 2010 года. В ходе заседания Межгосударственного совета ЕврАзЭС Президен- 
ты трех государств заявили о завершении I этапа формирования единой таможенной территории ТС.

18 ноября 2011 года в Москве главами трех государств подписаны документы следующего этапа интеграции: Декларации о Евразийской экономической интеграции, Договора о Евразийской экономической комиссии и Регламента работы Евразийской экономической комиссии.

Принятие Декларации о переходе с 1 января 2012 года к очередному этапу развития интеграции - Единому экономическому пространству (ЕЭП), в рамках которого действуют совместимые механизмы регулирования экономики, имеется единая инфраструктура и осуществляется согласованная политика, обеспечивающие свободное движение товаров, услуг, капитала и рабочей силы.

Сформирован единый постоянно действующий регулирующий орган ТС и ЕЭП - Евразийская экономическая комиссия, основной задачей которой является обеспечение условий функционирования и развития ТС и ЕЭП, а также - выработан ряд предложений по развитию интеграции на дальнейшую перспективу.

Следующая цель экономической интеграции - создание к 2015 году Евразийского экономического союза (с контрольным сроком предоставления на рассмотрение руководителей трех государств проектов соответствующей документации - 1-е мая 2014 года).

\section{Значение ЕЭП в деле защиты интересов его участников и как инструмента противодействия «внешним силам».}

Инициаторы данного проекта характеризуют его как перспективный, рассчитанный на ощутимое увеличение прибыли, получаемой всеми участниками в обозримом будущем. Однако, в реальности, за проект создания ЕЭП реализуется в контексте сложной системы геополитических взаимоотношений многих государств, в которую самую активную роль играют попытки вмешательства западных стран.

Для США и Великобритании, - которые и сейчас не скрывают своего интереса к этому региону, - Центральная Азия всегда была, и остается территорией стабильной привлекательности. Центральная Азия богата полезными ископаемыми разных видов. Кроме этого, для западных держав весьма полезно с геополитической точки зрения иметь в сфере своего влияния такой стратегически-важный регион.

Однако, на пути расширения своего влияния они сталкиваются с рядом препятствий, среди которых - влияние России и Китая в регионе. Вполне логичным для «запада», и, к тому же, достаточно действенным способом избавиться от такой помехи является создание ситуации, порождающей раздор сначала в среде политических и экономических «элит» России, Казахстана и Беларуси (a, заодно, - и других среднеазиатских государств), а затем распространить разногласия по всем социальным слоям, действуя согласно известному принципу «разделяй и властвуй».

Практикуются западными странами и меры организационно-экономического характера, также, несущие в себе элемент определенной деструктивности. Так, по мнению аналитиков ЕАБР, изучавших в январе 2013г. внешние угрозы и риски для формирующегося экономического пространства, наиболее негативно на интеграционные процессы в ЕЭП влияют, во-первых, стремление третьих стран экспортировать из Таможенного Союза (ТC) преимущественно сырьё, и во-вторых, стремление ВТО предъявлять странам ТС разноплановые требования, затрудняя выработку общих правил внутри ЕЭП.

И, вот, уже на протяжении многих лет можно наблюдать ведение целых кампаний 
по дестабилизации внутренней и внешней политико-экономической ситуации в государствах-участниках ЕЭП. В канве таких кампаний становится вполне понятным истинный смысл высказываемых рядом экспертов мнений, общая суть которых сводится к тому, что ЕЭП - это проект по восстановлению СССР. Прежде всего, подобные мнения выражают специалисты или политики, связанные с правительственными кругами США. При этом, нередко в той или иной форме звучат предупреждения, о недопустимости воссоздания СССР в каком бы то ни было формате, в том числе под вывеской экономической интеграции.

Однако, такие мнения имеют с реальностью не много общего. ЕЭП - проект, который реализуется с учётом опыта Евросоюза. Возьмем на себя смелость утверждать, что одна из главных причин того, что он выстраивается именно с учетом опыта, а не исключительно «по шаблону» создания ЕС в следующем: существуют разительные отличия в менталитете, отличия экономик переходного периода и специфики традиций политико-управленческой культуры на постсоветском пространстве от того, что наблюдается и сложилось на «западе», в странах с развитыми традициями рыночной экономики и выборной демократии.

Выше говорилось об экономической и социальной привлекательности проекта ЕЭП. Что касается политической привлекательности, - хотя не ей посвящена данная работа, - отметим, что политические аспекты рассматриваемого сотрудничества весьма значимы и не менее важны, чем экономические или социальные, но они способны оказывать воздействия как притягательного, так и центробежного характера. В связи с последним обстоятельством, отметим, что, наряду со стремлением к интеграции, отмечается, также, и определенное сопротивление государств ЕЭП политической интеграции на постсоветском пространстве, что выражается, прежде всего, в определенном интересе их руководства к другим вариантам межгосударственных альянсов. Так, Казахстанское руководство явно рассматривает, кроме ЕЭП, возможность участия страны в «Тюркском союзе», предполагающем объединение таких стран, как Кыргызстан, Казахстан, Узбекистан, Туркменистан, Азербайджан, Турция и Турецкая Республика Кипр; также заметным претендентом на создание экономических альянсов для России и Казахстана пока что является Китай.

\section{ЕЭП как среда для формирования единой региональной валюты.}

Вопрос о регулировании деятельности на финансовых рынках в рамках создания ЕЭП относится к числу наиболее важных. Среди документов, подписанных главами трех государств еще в декабре 2010 года, - Соглашение о создании условий на финансовых рынках для обеспечения свободного движения капитала и Соглашение о торговле услугами и инвестициях в государствах-участниках ЕЭП.

В рамках первого из них предлагаются меры по балансировке законодательств в области финансового регулирования, в том числе законодательных требований в банковской сфере, а также в таких областях, как страхование, рынок ценных бумаг, валютный рынок. Также, предусмотрены совместные действия сторон по обеспечению транспарентности деятельности участников финансового рынка. Результатом должно стать формирование общего финансового рынка с получением финансовыми компаниями стран-участниц ЕЭП возможностей доступа на национальные рынки друг друга.

Среди положительных эффектов ожидается рост доступности финансовых ресурсов для казахстанских, российских и белорусских финансовых организаций наряду с 
усилением их конкуренции на межстрановом (ЕЭП) уровне. ${ }^{7}$ Также, на соответствующих рынках каждой из стран-участниц, прогнозируется и взаимное увеличение объемов услуг, оказываемых банками, страховыми организациями и игроками рынков ценных бумаг.

К сожалению, здесь не обходится без ряда проблем.

Ожидание каждым государством, вошедшим в ЕЭП неблагоприятных последствий для ряда национальных отраслей замедляет принятие общих решений в ТС.

Для Казахстана, с характерным для него перекосом экспорта в сторону минерально-сырьевых ресурсов и вытекающей из этого зависимостью от мировой конъюнктуры спроса на них, - такими отраслями считаются большинство несырьевых отраслей, включая банковскую сферу или агропромышленный комплекс с его технологическим отставанием.

Для Белоруссии явно проблемной отраслью является агропром. Но здесь доминирует проблема дотаций. Дело в том, что после вступления в ТС Минск уже не может произвольно определять бюджетные средства в виде дотаций на поддержку сельского хозяйства: согласно правилам единой конкурентной политики ЕЭП, партнёры могут потребовать их снижения. Кроме того, ЕЭП снимает препятствия для российского и казахстанского капитала в ходе приватизации в Белоруссии.

Для России, тоже, далеко не весь «интеграционный небосклон» оказался «безоблачным». С началом функционирования ЕЭП, РФ должна была отказаться от субсидирования своего национального автопрома и производителей техники сельскохозяйственного назначения.

Можно выделить и ряд проблем общего характера.

${ }^{7}$ По материалам интернет-портала Kapital.kz. Источник: kap-
ital.kz/expert/12599/eep-otkroet-vozmozhnosti-ne-dlya-vseh.htm 88
Во-первых, - проблема достоверности и полноты таможенного информирования, обмена информацией между таможенниками стран ТС.

Во-вторых, - так называемая «статистическая проблема», выражающаяся в отсутствии статистики взаимодействия (около половины предприятий трех стран не сообщают органам статистики сведений о результатах своей деятельности).

В третьих, с началом развития ЕЭП, также активно, стали формироваться «условия для перетока капитала и ликвидных активов из стран с более жесткими регуляторными требованиями в страны с относительно мягким регулированием». ${ }^{8}$

\section{Перспективы ЕЭП - как территории региональной или наднациональной резервной валюты: проблемы и перспективы.}

Говоря о соответствующих перспективах, прежде всего следует иметь в виду, «что центральные (национальные) банки государств-участников ЕЭП могут проводить денежно-кредитную и курсовую политику независимо от согласованных интервальных значений макроэкономических показателей (цена на нефть марки Brent, темпы развития мировой экономики, курс национальных валют сторон к доллару США и / или евро).

Вопросы политики обменного курса являются особенно важными, поскольку связаны м необходимостью создания условий для расширения использования национальных валют во взаимных расчетах государств-участников ЕЭП. Договор о согласованной валютной политике (заключенный в реализацию Соглашения о согласованных принципах валютной политики) как раз закрепляет принятие сторонами

\footnotetext{
${ }^{8}$ По материалам интернет-портала Kapital.kz. Источник: kapital.kz/expert/12599/eep-otkroet-vozmozhnosti-ne-dlya-vseh.htm
} 
мер по координации курсовой политики, содействию расширению использования национальных валют во взаимных расчетах, созданию условий для размещения своих валютных активов в национальных валютах государств ЕЭП.

Деятельность по координации курсовой политики возложена на Консультационный совет по валютной политике, в состав которого входят руководители центральных (национальных) банков или их заместители». ${ }^{9}$

Ключевой проблемой, от разрешения которой, во многом, зависят темпы и характер развития интеграционных процессов не только в ЕЭП, но и в других объединениях, является замена мировых валют национального характера (и, прежде всего, главной из них - доллара США), новой, наднациональной валютой; такой валютой, которая была бы способна служить интересам широкого круга членов международного сообщества, а не только интересам, преимущественно, экономик стран «золотого миллиарда». В этом направлении существуют два пути - медленный, поэтапно-эволюционный и революционный, предполагающий стремительное, лавинообразное нарастание изменений. Первый предполагает создание на базе региональных экономических союзов сети их коллективных валют подобных евро, и затем - вытеснение из мирового оборота национальных валют; второй путь, обозначенный как «революционный», состоит в эмиссии на широкой международной основе наднациональной или «денационализированной» (термин Ф. фон Хайека) валюты.

Кратко охарактеризуем оба варианта.

Первый путь. Опыт внедрения и использования такой региональной валюты,

\footnotetext{
${ }^{9}$ Ковалева К.А. Единое экономическое пространство - защита от западного влияния // Материалы Интернет-ресурса www.group-global.org - интеллектуальная сеть Ассоциации «Евразийский экономический клуб ученых» в формате коммуникативной интернет-площадки G-Global (Источник: www. group-global.org/ru/advice/view/1594)
}

как евро показал, что она, в целом, стабильнее доллара и вполне может с ним конкурировать.

Однако региональные валюты - это лишь улучшенный вариант национальных, обслуживающий интересы четко «оконтуренной» группы, но не большинства стран. Региональные валюты не располагают общим государством - конечным кредитором, что может вызывать значительные колебания их курса по политическим причинам.

При этом, существует вероятность значительного неожиданного падения региональной валюты вследствие существенного несоответствия экономических параметров, прежде всего, производительности труда в странах-аутсайдерах и стране-локомотиве региональной интеграции. Именно это обстоятельство, скорее всего, представляет весьма серьезную опасность для коллективной валюты регионального характера как счетной единицы любых группировок стран с формирующимися рынками. И в этом плане, «евразийский рубль» мало чем отличается от динара ОАЭ или андского песо.

Второй путь, связанный с международной эмиссией денационализированной валюты. Он предполагает такие возможные варианты: (1) в рамках коллективно управляемого международного эмиссионного банка (как было предложено Д.М. Кейнсом еще в 1924-1944 годах) выпускать мировые деньги в объемах, соответствующих потребностям делового оборота, что, по сути, означает - на безинфляционной основе; (2) ликвидация монополии национальных денег, используемых в качестве мировых (в частности, доллара США) путем создания конкурентной валюты. Для этого потребуется (согласно идее Ф. фон Хайека) потребуется создать на международном рынке несколько частных эмиссионных центров, выпускающих валюты, способные конкурировать между собой и, за счет этого, обеспечивающие стабильность курса. В этом 
случае им удастся вытеснить из мирового оборота выпускаемые правительствами национальные деньги, которые носят инфляционный характер, поскольку, если эти деньги используются как резервные единицы, соответствующая монополия их выпускающих национальных правительств позволяет им навязывать свои деньги и резидентам, и внешнему миру.

Для того, чтобы покончить с монополией доллара и других валют национального характера на мировом рынке, как того требует вся логика развития процессов глобализации в мире, предлагается создать (под эгидой БРИК и, по возможности, ООН) международный государственный эмиссионный банк. Вот, что пишет об этом В.В. Шмелев. «Гарантией его демократического характера будет равномерное распределение голосов не по квотам в уставном капитале, а по принципу 1 пайщик - 1 голос. Это исключит засилье в институте богатых пайщиков с их крупными квотами. Данное правило потребует обеспечения курса новых денег с помощью валютной корзины, а не интервенций за счет ресурсов банка. Такую возможность предоставляет Ямайкская реформа. Данный метод апробирован успешным опытом евро. Чтобы стать мировыми деньгами, новая валюта должна в обязательном порядке быть принята в качестве своего инструмента международным финансовым рынком евровалют. Для этого необходимы два условия: чтобы ее курс был стабильнее, чем у доллара и у евро, и, кроме того, нужна обратная связь курсов самой корзины и входящих в ее состав валют. Данную жесткую привязку своей денежной единицы обязана поддерживать каждая страна, включившая свою валюту в корзину. При наличии такой привязки в сочетании с оптимально стабильным курсом предшественника евро - ЭКЮ, рынок евровалют принял его в качестве своего валютного инструмента еще задолго до ее официальной эмиссии в ЕС. ТНБ принимали к исполнению контракты, заключенные по приемлемому для них курсу этой виртуальной валюты, получившей от рынка неофициальное название «коммерческое ЭКЮ». Затем, при необходимости осуществить конечный расчет, они «ломали корзину», расплачиваясь в любой из включенных в нее реальных валют по курсу ее привязки. Более того, еврорынок может самостоятельно эмитировать в электронном виде любую используемую им валюту в десятикратном объемом к уже обращающейся на нем сумме. Такая «мультипликация»является депозитно-чековой. Она носит частный, и поэтому безынфляционный характер, поскольку деньги выпускаются для совершения реальных сделок, а не для покрытия дефицита бюджета, как это может иметь место при государственной эмиссии.

Включение валюты в корзину с обратной связью должно способствовать росту выраженных в ней операций и ее престижу на мировом рынке. Но для страны-эмитента такое положение ограничивает возможность проведения валютной политики. Станет затруднительно проводить национальную валютную политику: понижать курс для стимулирования экспорта или повышать его для привлечения капиталов. Но странам, стремящимся зафиксировать существующий курс вопреки требованиям контрагентов, изменять его, как КНР, включать в корзину новые деньги будет нежелательно, как и странам, стремящимся придать своим валютам международный статус: РФ, Саудовская Аравия или Объединенные Арабские Эмираты». ${ }^{10}$

\footnotetext{
${ }^{10}$ Шмелев В.В. Резервные валюты национального характера как объект реформирования мировой финансовой архитектуры // Экономика. С. 236-238.
} 


\section{Перспективы российского рубля как региональной резервной валюты}

Еще в 2007 - 2009 гг. кризисные явления продемонстрировали подверженность финансовых рынков ведущих экономик мира масштабным потрясениям системного характера. Одним из проявлений кризиса стало. Развитие кризиса характеризовалось высокой степенью нестабильности на мировом валютном рынке, падением объемов международной торговли и значительным оттоком капитала из развивающихся стран. Всё это актуализировало вопрос о целесообразности существования современной мировой валютной системы, основанной на использовании доллара США и еще нескольких резервных валют, самостоятельно эмитируемых центральными банками экономически развитых стран.

Под резервной понимается валюта, которую центральные банки и правительства различных стран используют для хранения своих резервов. ${ }^{11}$

Резервная валюта должна отвечать нескольким дополнительным признакам. Это должна быть стабильная валюта большой экономики с широкими внешнеэкономическими связями и развитым финансовым рынком.

Также, значимыми условиями становления резервной валюты являются: исторически обусловленная традиция ее использования в международной торговле, а также сетевой эффект. На сегодняшний день МВФ официально выделяет четыре резервные валюты: доллар США, евро, фунт стерлингов и японскую иену. ${ }^{12}$

Итак, первым, и самым явным признаком резервной валюты является ее использова-

\footnotetext{
${ }^{11}$ Словарь современной экономической теории Макмиллана. М.: ИНФРА-М, 1997.

${ }^{12}$ По материалам Интернет-портала ForexAW.com (Источник: http://forexaw.com/TERMs/Money/Currencies/11502_Резервная валюта_reserve_currency_это)
}

ние центральными банками и правительствами различных стран для хранения своих резервов.

Далее следуют такие признаки, как:

1) Стабильность валюты в качестве средства платежа (т.е. использование экономическими агентами резервной денежной единицы подразумевает минимальный риск потерь из-за колебаний ее стоимости; при этом, ее свободная конвертируемость, здесь, выступает одним из факторов стабильности валюты. Предполагается, что доверие экономических агентов вызывает устойчивость денежной единицы и возможность в любой момент свободного обмена её на другие валюты; следствием этого оказывается активное использование ее экономическими агентами для взаимных расчетов). ${ }^{13}$

2) Размер экономики страны-эмитента и ее доля в мировой торговле. ${ }^{14}$

3) Развитость и глубину национального финансового рынка ${ }^{15}$ (т.е. способность и возможности финансовых институтов страны быстро и с низкими затратами привлекать заемные средства, вкладывая их в надежные и достаточно доходные инструменты, повышают вероятность прихода иностранных инвесторов на внутренний финансовый рынок. Отсюда следует, что, валюта страны, имеющей хорошо развитый внутренний финансовый рынок, будет более широко использоваться на международных рынках капитала).

4) Исторический фактор формирования резервных валют ${ }^{16}$ (из опыта деловой практики известно, что процесс использования какой-либо валюты в качестве резервной,

\footnotetext{
${ }_{13}^{13}$ Там же.

14 Там же.

${ }^{15}$ Greenspan A. The Euro as an International Currency. Remarks Before the Euro 50 Group Roundtable. Washington, D. C. November 30, 2001.

${ }^{16}$ Frankel J. A. Reports of the Dollar's Demise are Greatly Exaggerated. Berkeley: University of California, 1995.
} 
во многом, определяется сложившейся деловой практикой, для которой характерно, что конкретные экономические агенты чаще проявляют склонность к применению в своих расчетах той валюты, которой пользуются все остальные.)

5) Сетевые внешние эффекты ${ }^{17} 18$ (это дополнительная ценность, которую получает потребитель конкретной ценности в том случае, когда общее количество её потребителей увеличивается; отсюда следует, что чем больше экономических агентов используют валюту в расчетах, тем чаще ею будут пользоваться и другие).

Резервная валюта выполняет в мировой платежной системе ряд определенных функций, ориентированных на удовлетворение потребностей экономических агентов в средствах расчета, средствах платежа и средствах сохранения ценности.

В данном случае, имеется в виду следующее.

Основная функция резервной валюты заключается в том, чтобы за счет улучшения координации сделок на валютном рынке и снижения транзакционных издержек при проведении внешнеторговых операций, облегчить международный обмен товарами и услугами. Еще, резервные валюты могут использоваться в качестве средства сохранения ценности, а также - центральными банками большинства стран мира - как резервы. Спрос на резервные валюты зависит от выполняемых ими функций в международных сделках. ${ }^{19}$

Функции резервной валюты (ниже, приводятся как фкункции, связанные с

\footnotetext{
${ }^{17}$ Chinn M., Frankel J. The Euro May Over the Next 15 Years Surpass the Dollar as Leading International Currency // NBER Working Paper. No. 13 909. April 2008.

${ }^{18}$ Моисеев С. Рубль как резервная валюта // Вопросы экономики. 2008. № 9.

19 Трунин П.В., Наркевич С.С. Перспективы российского рубля как региональной резервной валюты. Серия «Научные доклады: экономика». М.: Издательский дом «Дело» РАНХиГС, 2013. - C. 5.
}

использованием частными валюты экономическими агентами, так и сопряжённые с использованием монетарными властями):

служить средством расчета (определение цен в международной торговле; определение валютных курсов и паритетов валют),

служить средством платежа (промежуточная валюта в обменных операциях; валюта, с помощью которой осуществляются интервенции на валютном рынке),

служить средством сохранения ценности (валюта депозитов, кредитов, ценных бумаг; валюта хранения официальных резервов). ${ }^{20}$

Обычно спрос на резервную валюту разделяют на спрос со стороны частных экономических агентов и спрос со стороны центральных банков. Частными экономическими агентами резервная валюта используется для проведения внешнеторговых сделок, как промежуточная валюта в операциях по обмену валют и как валюта номинирования корпоративного долга. Центральные же банки используют резервную валюту в качестве ориентира при установлении обменного курса, для проведения валютных интервенций и для хранения официальных резервов. ${ }^{21}$

Перечислим главные из преимуществ и недостатков обладания резервной валютой.

Преимущества для страны-имитента:

гибкость фискальной политики;

гибкость политики платежного баланса; сеньораж ${ }^{22}$;

преимущества для ведения бизнеса и удобство для резидентов.

Основные недостатки обладания резервной валюты для страны-имитента:

\footnotetext{
${ }^{20}$ Kennen P. B. The Role of the Dollar as an International Currency. New York: Group of Thirty, 1983.

21 Экономический портал Institutiones.Com (Источник: http://institutiones.com/general/2146-perspektivy-rublya-kakregionalnoj-rezervnoj-valyuty.html)

${ }^{22}$ Обладание государством резервной валютой в рамках мировой экономики дает возможность получать прямой доход от выпуска денег.
} 
снижение эффективности денежно-кредитной политики (Центральный банк страны-эмитента резервной валюты не может так же быстро реализовывать меры по контролю за денежным предложением внутри страны, как другие страны);

возможное укрепление курса данной валюты, ведущее к ослаблению конкурентных преимуществ экспортеров. ${ }^{23}$

Возможности осуществлять эмиссию резервной валюты предполагают определенные преимущества и недостатки. Среди преимуществ для страны-эмитента выделяют гибкость налогово-бюджетной политики, гибкость внешнеторговой политики, дополнительные доходы от сеньоража и удобство для ведения международного бизнеса резидентами данной страны. Основным же недостатком является ограничение гибкости денежно-кредитной политики.

Однако, такая сторона эмиссии, как использование резервной валюты экономическими агентами других стран, также предполагает для них наличие как преимуществ, так и недостатков. При этом, преимущества, связаны с возможностью управления валютным риском при проведении внешнеторговых сделок, а также - с повышением доверия к экономической политике страны, обладающей резервами, обращенными в резервные валюты.

Еще одно преимущество состоит в стабильности используемой резервной валюты в случае отказа страны от эмиссии собственной денежной единицы, но при этом существенными недостатками оказываются потеря как независимости денежно-кредитной политики, так и потеря доходов от сеньоража.

Значит, помимо использования центральными банками для хранения своих ре-

${ }^{23}$ Трунин П.В., Наркевич С.С. Перспективы российского рубля как региональной резервной валюты. Серия «Научные доклады: экономика». М.: Издательский дом «Дело» РАНХиГС, 2013. - C. 22. зервов, резервная валюта должна обладать определенными свойствами и выполнять ряд других функций. ${ }^{24}$

Общий спрос на резервную валюту складывается из нескольких составляющих: из спроса для проведения торговых транзакций и спроса со стороны международных финансовых рынков. Основными факторами, которые положительно влияют на использование резервной валюты на международных рынках, являются стабильность данной валюты по сравнению с другими валютами, степень конкурентоспособности компаний страны-эмитента и эластичности спроса в ней на импортные товары, величина издержек по проведению валютных сделок с данной валютой, а также валютная структура внешней торговли и потоков капитала стран-инвесторов в активы в данной валюте. Важно отметить, что на данный момент не проводилось моделирование совместного влияния всех факторов спроса на резервные валюты, поэтому определить степень влияния того или иного фактора достаточно сложно.

До сих пор резервные валюты и спрос на них преимущественно анализировались в масштабах всей мировой экономики. Вместе с тем спрос со стороны внешних экономических агентов наблюдается и для некоторых других валют. Обычно их использование ограничено несколькими странами, которые граничат или активно торгуют со странойэмитентом такой валюты, поэтому их принято называть региональными резервными валютами.

«Региональной резервной принято называть такую валюту, которая выполняет все или часть функций резервной валюты, но не в мировом, а в региональном масштабе, т. е. когда данную валюту начинают использовать в своих транзакциях нерезиденты

\footnotetext{
${ }^{24}$ По материалам Интернет-портала ForexAW.com (Источник: http://forexaw.com/TERMs/Money/Currencies/11502_Резервная валюта reserve currency это)
} 
близлежащих стран вне пределов юрисдикции страны-эмитента». ${ }^{25}$ Соответствующие положения можно найти в ряде работ. Это значит, что «региональная резервная валюта должна входить в резервы центральных банков стран, близких по географическому расположению, а также по масштабу торговых и инвестиционных потоков. Она также должна использоваться в качестве промежуточного инструмента, способствующего снижению транзакционных издержек, которые возникают при обмене региональных малоиспользуемых валют. Возможно также, что в некоторых случаях региональная резервная валюты может использоваться в качестве меры стоимости, т. е. для определения цен в тех странах региона, которые испытывают сложности с проведением стабильной монетарной политики.

В узком смысле под региональной резервной валютой может пониматься денежная единица некоторой страны, которую хранят в качестве резервов или используют в операционной деятельности центральные банки хотя бы нескольких стран». ${ }^{26}$

Существуют, по крайней мере, 4 страны, денежные единицы которых отвечают обозначенным параметрам - это Китай, Индия, Бразилия, Россия.

В заключение, необходимо отметить следующее. Сегодня доля региональных резервных валют в мировой экономике остается небольшой. Тем не менее, в последние годы роль региональных валют растет. Среди них на данный момент наиболее используемыми являются австралийский, канадский и гонконгский доллары. Доля остальных региональных валют менее значительна, однако использование некоторых

\footnotetext{
25 Экономический портал Institutiones.Com Com (Источник: http://institutiones.com/general/2146-perspektivy-rublya-kak-regionalnoj-rezervnoj-valyuty.html)

26 Экономический портал Institutiones.Com Com (Источник: http://institutiones.com/general/2146-perspektivy-rublya-kak-regionalnoj-rezervnoj-valyuty.html)
}

из них увеличивается очень быстрыми темпами. В качестве самых динамично растущих валют можно выделить китайский Юань, индийскую рупию и российский рубль. ${ }^{27}$

Региональная торговля между странами бывшего СССР и наличие емкого внутреннего рынка позволяют российскому рублю повышать свою роль на постсоветском пространстве. Однако, несмотря на то, что доля российского рубля на международном рынке быстро увеличивается, конкуренция со стороны других валют является существенным негативным фактором для перспектив превращения рубля в региональную резервную валюту. Кроме того, близость стран региона к двум другим большим рынкам - китайскому и европейскому - не позволяет однозначно говорить о продолжении доминирования России в региональной торговле. ${ }^{28}$

По этой причине актуальной задачей является разработка и использование комплекса мер, способных содействовать достижению рублем статуса региональной резервной валюты.

Решение задачи по повышению статуса валюты до уровня региональной резервной требует выделения факторов, которые этому способствуют.

Факторы спроса на резервы в определенной валюте со стороны центрального банка:

1) активная международная торговля со страной - эмитентом данной валюты (связана с необходимостью поддержки платежного баланса в случае возникновения временного отрицательного сальдо торгового баланса),

2) величина внешней задолженности, номинированной в данной валюте (связана с необходимостью поддержки платежного

\footnotetext{
27 Там же.

${ }^{28}$ Трунин П.В., Наркевич С.С. Перспективы российского рубля как региональной резервной валюты. Серия «Научные доклады: экономика». М.: Издательский дом «Дело» РАНХиГС, 2013.
} 
баланса в случае возникновения временного отрицательного сальдо счета операций с капиталом и финансовыми инструментами),

3) доходность активов центрального банка в данной валюте (со стремлением ЦБ получать максимальную доходность по портфелю резервов при минимальном риске). ${ }^{29}$

Специалисты отмечают, что наибольшие перспективы расширения рублевой торговли в СНГ связаны, в настоящее время, с предоставлением специального краткосрочного торгового финансирования в рублях импортерам из стран Содружества. Из-за трудностей с получением финансирования, в текущих условиях такой инструмент мог бы быть вполне востребованным и позволил бы расширить «внешнее» использование рубля. ${ }^{30}$

Таким образом, для того, чтобы валюта конкретного государства приобрела статус региональной резервной валюты должно быть обеспечено такое развитие экономики страны-её эмитента, при котором она: во-первых, станет основным конечным потребителем товаров и услуг, производимых в соседних странах, во-вторых, будет инвестировать средства в активы стран-партнеров, и, в-третьих, будет в состоянии обеспечивать приемлемую доходность по активам, номинированным в своей валюте.

Кроме этого, заметим, что дальнейшее укрепление авторитета рубля и расширение выраженных в нем операций мирового рынка в немалой степени связано с тем, насколько Россия в дальнейшем будет проявлять активность в борьбе за демократизацию мировой финансовой архитектуры. Кроме всего прочего, это будет способствовать и укреплению роли рубля на территории постсоветских государств и их союзов.

\section{Библиография:}

1. Шмелев В.В. Резервные валюты национального характера как объект реформирования мировой финансовой архитектуры // Экономика. С. 236-238.

2. Трунин П.В., Наркевич С.С. Перспективы российского рубля как региональной резервной валюты. Серия «Научные доклады: экономика». М.: Издательский дом «Дело» РАНХиГС, 2013.

3. Dobson W., Masson P. R. Will the Renminbi Become a World Currency? Canadian Economics Association, 2009.

4. Genberg H. Currency Internationalisation: Analytical and Policy Issues. Bank for International Settlements, 2009.

5. Salikhov M., Agibalov S. The Rouble as the Settlement Currency of the CIS // Eurasian Integration Yearbook 2010. Eurasian Development Bank. Almaty, 2010.

6. [Электронный pecypc]. - Режим доступа: www.memoid.ru (дата обращения 12.05.2014)

7. Евразийское экономическое сообщество [Электронный ресурc]. - Режим доступа: www. evrazes.com (дата обращения 12.05.2014)

8. Консультативно-правовой ресурс. Евразийская экономическая интеграция: ЕврАзЭС Таможенный союз - ЕЭП [Электронный ресурс]. - Режим доступа: www.customs-union. com (дата обращения 12.05.2014)

9. [Электронный peсурс]. - Режим доступа: www.group-global.org (дата обращения 12.05.2014)

10. Терминологический глоссарий [Электронный ресурс]. - Режим доступа: www.kremlin.ru/ terms/e (дата обращения 12.05.2014)

\footnotetext{
29 Экономический портал Institutiones.Com Com (Источник: http://institutiones.com/general/2146-perspektivy-rublya-kak-regionalnoj-rezervnoj-valyuty.html)

${ }^{30}$ www.group-global.org/ru/publication/view/8437
} 
DOI: $10.7256 / 2226-6305.2015 .1 .13487$

При цитировании этой статьи сноска на dоі обязательна

Международное право и международные организации•1•2015

International Law and International Organizations

11. Капитал. Центр деловой информации [Электронный ресурc]. - Режим доступа: www. Kapital.kz (дата обращения 12.05.2014)

12. Валютный рынок - аналитика форекс [Электронный ресурc]. - Режим доступа: www. Forex AW.com (дата обращения 12.05.2014)

13. Экономический портал [Электронный ресурс]. - Режим доступа: Institutiones.Com (дата обращения 12.05.2014)

\section{References (transliterated):}

1. Shmelev V.V. Rezervnye valyuty natsional'nogo kharaktera kak ob'ekt reformirovaniya mirovoi finansovoi arkhitektury // Ekonomika. S. 236-238.

2. Trunin P.V., Narkevich S.S. Perspektivy rossiiskogo rublya kak regional'noi rezervnoi valyuty. Seriya «Nauchnye doklady: ekonomika». M.: Izdatel'skii dom «Delo» RANKhiGS, 2013.

3. Dobson W., Masson P. R. Will the Renminbi Become a World Currency? Canadian Economics Association, 2009.

4. Genberg H. Currency Internationalisation: Analytical and Policy Issues. Bank for International Settlements, 2009.

5. Salikhov M., Agibalov S. The Rouble as the Settlement Currency of the CIS // Eurasian Integration Yearbook 2010. Eurasian Development Bank. Almaty, 2010. 